\title{
Staying or Leaving? Analyzing the Rationality of Rural-Urban Migration Associated with Farm Income of Staying Households: A Case Study from Southern Ethiopia
}

\author{
Beneberu Assefa Wondimagegnhu \\ Department of Rural Development and Agricultural Extension, Bahir Dar University, P.O. Box 2289, Bahir Dar, Ethiopia \\ Correspondence should be addressed to Beneberu Assefa Wondimagegnhu; benassefa2006@gmail.com
}

Received 28 September 2014; Accepted 16 December 2014

Academic Editor: Tibor Janda

Copyright (C) 2015 Beneberu Assefa Wondimagegnhu. This is an open access article distributed under the Creative Commons Attribution License, which permits unrestricted use, distribution, and reproduction in any medium, provided the original work is properly cited.

\begin{abstract}
The research aims at analyzing the effect of rural-urban migration and remittances on farm income of rural households supported by a case study conducted in Southern Ethiopia. Using two-step estimations to measure the effect of outmigration, migrant sending families have gained higher farm income. In this regard, rural outmigration has been found to be a survival and income diversification strategy in the study area.
\end{abstract}

\section{Introduction}

Economic growth and development have long been associated with rural-urban migration in many economic publications. From the historical point of view, the current developed world in 19th and early 20th century has undergone different patterns of migration, predominantly rural-urban migration attributed to the process of industrialization and economic development. In addition, the percent of population living in the urban areas has grown rapidly and urbanization has been fueled by rural-urban migration [1-3].

Sub-Saharan Africa has experienced a noticeable increasing rate of rural-urban migration in recent years [4]. The increment in the rate of migration is associated with so many interrelated factors that determine the decision to move. According to Greenwood [5], some of the responsible factors for migration are classified based on regional differences between sending and receiving regions and on individual characteristics of migrants. In the same line, Naude [4] and Ivan [6] classified the determinants that affect the migration decision of individuals and families in sub-Saharan Africa as economic determinants, demographic determinants, gravity variables, labor market determinants, and conflict and environmental determinants. According to a report from Marchiori et al. [7], climate variation has been responsible for a displacement of 2.55 million people over the period of 1960 2000 in Sub-Saharan Africa. The problem is particularly severe for countries that depend on the agriculture sector and has led to rural-urban migration as well as shift from agricultural to nonagricultural sector.

Surveys conducted on the impact of rural-urban migration on the development of local economies in Sub-Saharan Africa show different results and the direct and indirect effects vary from country to country. On one hand, some studies such as Lipton [8] depicted that migration is often observed among the most productive group of the population and leading to lack of labor that eventually reduce rural production. In addition, the amount of remittance sent to the remaining rural families hardly enables us to use labor saving technologies and most of the portion of remittances is spent for day to day consumption. The average amount of remittances sent to rural villages was reported to be low and families of the migrants face difficulties to spend the money on agricultural investment due to high prices of production inputs such as chemical fertilizers, livestock breeds, and hired labor. On the other hand, studies such as Taylor [9], de Brauw et al. [10], Rosenzweig [11], Taylor et al. [12], and Gubert [13] depicted that remittances sent by migrants relax the credit constraints particularly among the poor rural farmers leading to the use of improved technologies. Remittances in 
the rural origin can be used for different purposes either for consumption or for capital expenditure or to insure rural households against volatile incomes or for investment on farming tools, inputs, and hired labor. In food insecure areas, remittances have played a vital role in ensuring food security and diversify risks. The average agricultural productivity in Sub-Saharan Africa measured in output of cereal per hectare is far below the average productivity in other regions. One of the reasons for this problem has been low investment on land fertility [14].

Ethiopia is one of the Sub-Saharan African countries experiencing high level of rural-urban migration. Currently, the rural population in Ethiopia is rising at a faster rate than the farm income and the productivity of labor is estimated to be less than one-fifth of the average for Sub-Saharan Africa. In general low yield, low soil fertility, fragmentation of land, and rising rural population have been reported to be the main responsible factors that have led the productivity of farm labor to be low. As a result, it is one of the reasons for the widespread of poverty in the country. This calls for some measures such as improving the productivity of land, introducing labor productivity, enhancing technologies, and expansion of nonfarm sectors as well as easing the obstacles of migration of labor [15].

Despite the fact that rural-urban migration has a long history in Ethiopia, research on the nexus between ruralurban migration and rural development is highly hampered by empirical evidences both from the perspective of migrant sending regions (rural and agricultural regions) and from migrant receiving regions (industries and urban centers). This has led to poorly designed migration and population policies as well as to ill-conceived rural and urban development policies. Thus, the research aims to assess and measure the effect of rural-urban migration on farm income rural households, with certain evidences from Southern Ethiopia.

\section{Conceptual Framework}

As a result of remittances $\left(Y_{R}\right)$, total household income $\left(Y_{T}\right)$ of migrant sending families at origin is expected to change and that leads to change in consumption and saving/investment of migrant sending households at origin. Remittances can directly contribute to changes in total household income- $Y_{T}$ or indirectly via investment on farm capital stock that changes the farm income $\left(Y_{F}\right)$ and thereby changes $Y_{T}$. Outmigration and remittances influence farm income of migrant sending families via affecting factors of production as follows.

Farm income of rural households at origin $\left(Y_{F}\right)$ is a function of production factors; that is,

$$
Y_{F}=Y_{F}(K, L, \mathrm{Ld})
$$

where $K$ is capital stock used for farm production, $L$ is labor force available in the household, and Ld is farm land holding.

Rural outmigration and flow of remittances affect labor and capital inputs, respectively, and thereby influence farm income $\left(Y_{F}\right)$. To begin with the labor input, rural outmigration reduces labor force and leads to changing the total labor available in migrant sending rural households; that is,

$$
\Delta L=-M_{N}
$$

where $M_{N}$ is the number of outmigrants to urban destination.

The amount of labor input available for farm activities is not only determined by the number of outmigrants but also by additional household characteristics; that is,

$$
L=L\left(M_{N}, Z_{\mathrm{HH}}\right)
$$

where $Z_{\mathrm{HH}}$ is household characteristics that influence the availability and allocation of labor for farm production. These include characteristics such as household size and number of dependents.

On the other hand, the investment on capital stock would be explained as a result of the savings, which is in turn explained as a resultant effect of the savings from farm income, remittances, and migration cost (MC). MC is incurred by migrant sending households while sending migrants to urban destination. MC is implicitly assumed as part of investment by migrant sending households with the expectation of remittances afterwards; that is,

$$
S_{i}=s_{i}\left(Y_{F}+Y_{R}\right)-\mathrm{MC}=\Delta K,
$$

where $S_{i}$ is total saving at origin, which is the net effect of saving rate from farm income $\left(s_{i} Y_{F}\right)$, saving rate from remittance income $\left(s_{i} Y_{R}\right)$, and migration cost (MC).

Figure 1 sums up the interrelated linkages between determinants of migration possible effects on total income of rural households in a least developed countries context. The framework has benefited from the works of Harris-Todaro [16] as well as from the New Economics of Labor Migration (NELM) model of migration [9].

\section{Material and Methods}

The case study was conducted in Shebedino district, southern Ethiopia, in the year 2010. The region for this particular case study was purposefully selected because migration of labor is prevalent in this particular region and is known for sending out labor migrants to destination locations such as to agroprocessing industries and state farms. The region has the highest population density and is one of the conflict free areas. In addition, the region is also characterized by its fertile land suitable for cereal production and most importantly known for its cash crop production, that is, coffee. This helps to see the links between multiplier effects of migration and local production and total income of migrant sending households. The district comprises 32 rural villages in total. Out of the list of these villages, four villages were selected using simple random sampling technique. The selected villages from Shebedino district are Taramessa, Furra, Medregenet, and Dobonegasha. In total, 259 households were selected out of 4 villages representing 1853 family members. The proportion of sample for each village depends on the total population in each village. On the other hand, representatives 


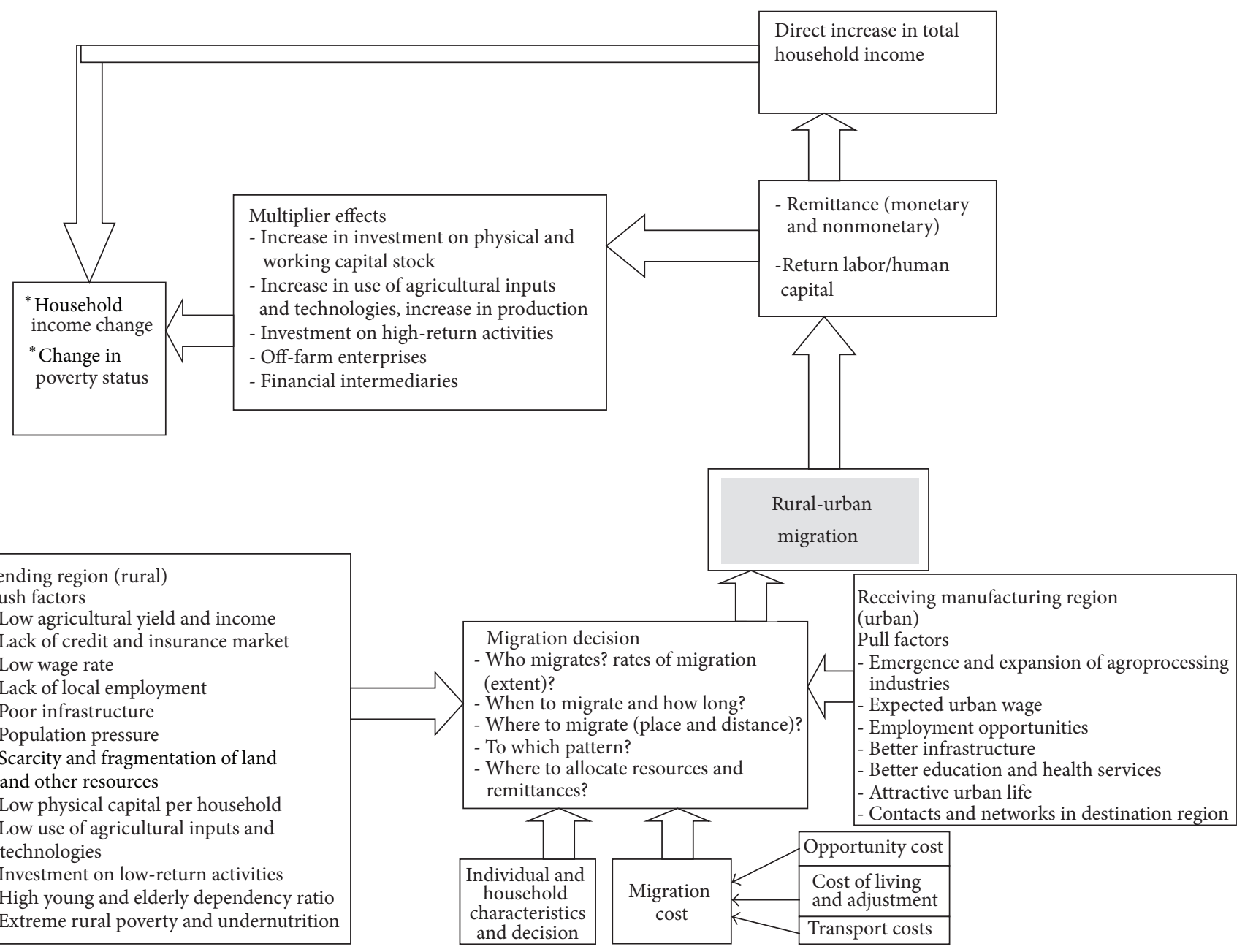

FIGURE 1: Interrelated linkages between determinants of migration and possible effects on total income in the least developed countries context (enriched from $[9,16])$.

of key informants and officials in each sampled village were selected to gather general information about the research area.

Both primary and secondary data were collected for the research. Semistructured individual interview was undertaken as the main data collection technique while doing the household survey. The use of individual interview method helps to keep the privacy of respondents and in the free flow of information especially in discussing sensitive issues. Group discussion with selected community members was carried out for each sample village for certain questions in the research topic. For the household survey, data is collected for observation period between 2006 and 2010 cropping years and the average estimation is presented in this paper.

The analysis of the effect of rural-urban migration on farm production and income has been analyzed in two stages. The first stage analyses the effect of outmigration and remittances on production factors and then the second stage estimates the effect on farm income based on the estimations made in the first stage. The second stage has used the Cobb-Douglass production function to derive its econometric model. STATA software package (version 11) was used for data analysis.

\section{Specification of Econometric Models}

Stage 1. In the first stage, factors affecting the allocation of labor and capital inputs are analyzed, including the characteristics of migration variables as determinant factors. Migration involves the removal of labor in one hand and the flow of remittances on the other that alters the available labor and capital input, thereby affecting farm income. In order to capture the differences within different migration patterns, the analysis is done for both temporary and permanent patterns of migration. Nonmigrant sending households are taken as control groups.

The determinants of available labor in a household are given by

$$
L_{(T)}=\alpha_{0}+\alpha_{1} M_{N}+\alpha_{2} N_{\mathrm{HH}}+\alpha_{3} D_{\mathrm{HH}}+\varepsilon_{L_{T}}
$$


and (for comparison between nonmigrant sending and temporary migrant sending households)

$$
L_{(P)}=\beta_{0}+\beta_{1} M_{N}+\beta_{2} N_{\mathrm{HH}}+\beta_{3} D_{\mathrm{HH}}+\varepsilon_{L_{P}}
$$

(for comparison between nonmigrant sending and permanent migrant sending households), where $L$ is farm labor available in a household at given time of farming. $L_{(T)}$ and $L_{(P)}$ are labor variables for comparison with respect to temporary and permanent patterns of migration, respectively. $M_{N}$ is the number of migrants in a household, $N_{\mathrm{HH}}$ is the size of a household, and $D_{\mathrm{HH}}$ is the number of dependents in a household. $N_{\mathrm{HH}}$ and $D_{\mathrm{HH}}$ are household characteristics that can determine the availability and allocation of labor input.

Similarly, the determinants of capital stock for migrant sending households are given by

$$
K_{(T)}=\gamma_{0}+\gamma_{1} Y_{R}+\gamma_{2} Y_{F}+\gamma_{3} \mathrm{MC}+\varepsilon_{K_{T}}
$$

and (for comparison between nonmigrant sending and temporary migrant sending households)

$$
K_{(P)}=\delta_{0}+\delta_{1} Y_{R}+\delta_{2} Y_{F}+\delta_{3} \mathrm{MC}+\varepsilon_{K_{P}}
$$

(for comparison between nonmigrant sending and permanent migrant sending households), where $K$ is farm capital stock allocated for agricultural production (including physical capital such as farm implements and hoes, draft animals, and working capital such as purchased chemical fertilizers, improved seeds, and pesticides valued in monetary terms). $K_{(T)}$ and $K_{(P)}$ are capital stock variables for comparison with respect to temporary and permanent patterns of migration, respectively. $Y_{R}$ is remittance income. Increase in the amount of remittance income predicts the enhancement of savings and investment on capital stock. $Y_{F}$ is farm income. Increase in the amount of farm income in turn boosts savings and investment on capital stock. MC is migration cost. Migrant sending households incur cost of migration as part of initial investment while sending migrants.

Stage 2. In the second stage, the predicted values of labor and capital inputs (in the first stage estimation) for both temporary and permanent patterns of migration are then used as a regressor in the second stage. In the second stage, the predicted values of labor and capital variables including the exogenous variable land $(\mathrm{Ld})$ are taken as explanatory variables for farm income. In order to do so, the CobbDouglass type production function is adopted to derive the second stage econometric model.

The Cobb-Douglass type production function is given by

$$
Y_{F}=A L^{\alpha} K^{\beta} \operatorname{Ld}^{\gamma},
$$

where $Y_{F}$ is farm output at a given farming season measured in Ethiopian Birr (ETB). Farm income is calculated by summing up sale of produced crop and livestock sale. Average price of the respective produces is considered to see the differences in terms of output/production. $L$ is labor input, $K$ is farm capital stock, and Ld is farm land holding available for cultivation measured in hectares, $A$ is total factor productivity and is estimated as a constant in the econometric model, and $\alpha, \beta$, and $\gamma(1-\alpha-\beta)$ are partial elasticities of farm income with respect to labor, capital, and land variables, respectively. They tell us the extent of the response/change of farm income as a result of change in inputs of labor, capital, and land holding, respectively.

The linear econometric model in the second stage embeds the predicted values (the predicted estimations $\widehat{L}_{(T)}, \widehat{L}_{(P)}$, $\widehat{K}_{(T)}$, and $\widehat{K}_{(P)}$ from (5), (6), (7), and (8), respectively, are converted to natural logarithms to fit them to the (10) and (11)) of the first stage estimation, plus land as exogenous variable as indicated in (10) and (11) below:

$$
\begin{aligned}
\ln Y_{F(T)}= & \eta_{1}+\alpha_{1} \ln \widehat{L}_{(T)}+\beta_{1} \ln \widehat{K}_{(T)} \\
& +\gamma_{1} \ln \operatorname{Ld}_{(T)}+\varepsilon_{Y F(T)}
\end{aligned}
$$

(comparison 1: nonmigrant sending versus temporary migrant sending households) and

$$
\begin{aligned}
\ln Y_{F(P)}= & \eta_{2}+\alpha_{2} \ln \widehat{L}_{(P)}+\beta_{2} \ln \widehat{K}_{(P)} \\
& +\gamma_{2} \ln \operatorname{Ld}_{(P)}+\varepsilon_{Y F(P)}
\end{aligned}
$$

(comparison 2: nonmigrant sending versus permanent migrant sending households), where $\widehat{L}_{(T)}$ and $\widehat{L}_{(P)}$ are the predicted estimations of labor from (5) and (6), respectively, $\widehat{K}_{(T)}$ and $\widehat{K}_{(P)}$ are the predicted estimations of capital from (7) and (8), respectively, and $\eta_{1}$ and $\eta_{2}$ are constants for comparisons 1 and 2, respectively.

\section{Results and Discussion}

\subsection{Rural-Urban Migration and Production Factors}

5.1.1. Effect on Farm Labor. Table 1 estimates the determinants of labor input among rural households. The estimation results in Table 1 are presented for both temporary and permanent patterns of migration. The results are to be interpreted in comparison against nonmigrant sending households.

The OLS estimation result (in Table 1) shows the determinants of labor input in both temporary and permanent patterns of migration. The coefficient of determination for the estimation in both types of comparisons shows that about $75.8 \%$ and $73.6 \%$ of the changes in labor hours among temporary and permanent migrant sending households, respectively, are explained by the changes in the number of migrants, size of a household, and number of dependents. The estimations show that outmigration of a family member in temporary and permanent migrant sending households reduces labor hours by 271.7 and 332.2 units, respectively, compared to nonmigrant sending households. The size of a household is also found to affect the allocation of labor hours positively and significantly in both types of estimation. The average estimation results show that the increment of household size by additional member leads to 690.8 and 681.8 unit increases in labor hours of temporary and permanent 
TABLE 1: Stage 1 estimation result for the determinants of labor input (for comparison of both temporary and permanent migrant sending households).

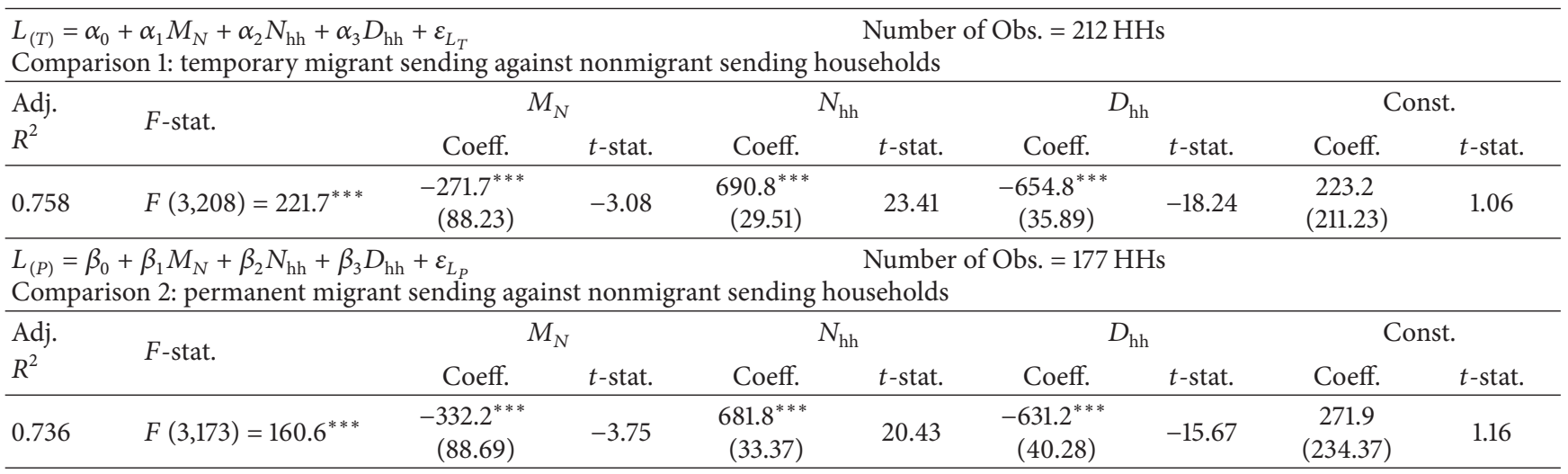

${ }^{*}$ refers to significant at $10 \%(P<0.1) ;{ }^{* *}$ refers to significant at $5 \%(P<0.05)$ and ${ }^{* * *}$ refers to significance at $1 \%(P<0.01)$.

Robust standard errors are found in parenthesis, source: author's estimation.

migrant sending households, respectively. The estimated results have produced significant and positive relationships between labor allocation and household size. Similarly, the relationship between labor-hour allocation and number of dependents in a household has been found to be negative. An increase in a dependent family member in a household, on average, has reduced the allocation of labor hours on farming activities by 654.8 units among temporary migrant sending households and by 631.2 units among permanent migrant sending households. Households with a more number of dependents (young children and elderly) are supposed to take care of the dependents left in the house and that hampers the time to be allocated for farm activities. The F-tests for both types of comparison as well as for each period of observation have also produced significant results. The estimation results in general confirm the hypothesis that available labor in a household is negatively influenced by the number of outmigrants and dependents in a household and positively affected by the household size. Migrant sending rural households make a collective decision to send migrants either temporarily or permanently based on the resources they have. Nonmigrant sending households have allocated the highest amount of labor hours as result of involving more workers in farm activities as well as allocation of more hours in farm compared to migrant sending households. Both permanent migrant sending and temporary migrant sending households allocated almost the same amount of hours in farm activities. However, on average, permanent migrant sending households have greater number of family members working in the field and are more able to send migrants to destination than temporary migrant sending households.

5.1.2. Impact on Farm Capital Stock. The OLS estimation (in Table 2) presents the estimation results regarding the determinants of capital stock of rural households. As usual comparison is done between nonmigrant sending and temporary migrant sending households as well as between nonmigrant sending and permanent migrant sending households. The estimation results presented for both temporary and permanent migrant sending households are interpreted with comparison against nonmigrant sending households.

As it is possible to see the coefficient of determination for the results in Table 2, about $34.2 \%$ and $27.4 \%$ of changes in capital stock of temporary and permanent migrant sending households are explained by the changes in remittance income, farm income, and cost of migration. According to the estimation, remittance income has shown positive and significant effect for capital stock investment in temporary migrant sending households. According to the result, a 10\% increase in remittance income leads to $2.3 \%$ increase in the amount of capital stock in temporary migrant sending households. The estimation result for comparison with permanent migrant sending households has produced insignificant results. This is in connection with the amount of remittances received by permanent migrant sending households, which is lower than temporary migrant sending households. Permanent migrants invest more in the destination and start up their own family and they send only a smaller proportion of remittance to their families living in rural areas than temporary migrants who return back to their origin with their savings.

Farm income has been found to affect the capital stock positively in both types of comparisons. This means the increment in the amount of farm income predicts increased investment on capital stock. According to the estimation in Table 2, a $1 \%$ increase in farm income leads to an increase of capital stock by $0.09 \%$ in both temporary and permanent migrant sending households, depicting that higher income from farm increases the savings and then investment on capital stock that in turn enhances farm production and income in the following cropping season. The effect of migration cost on capital stock for both patterns of migrant sending households is found to be insignificant. This means that capital stock of migrant sending households is almost not depleted as a result of sending migrants (for both temporary and permanent migrant sending households). The cost of migration can be sponsored from the savings from farm income, from relatives/friends in origin or destination region, or from loans. The $F$-tests for both types of comparison and period of observation have also produced significant results. 
TABLE 2: Stage 1 estimation result for the determinants of capital stock.

\begin{tabular}{ll}
\hline$K_{(T)}=\gamma_{0}+\gamma_{1} Y_{R}+\gamma_{2} Y_{F}+\gamma_{3} \mathrm{MC}+\varepsilon_{K_{T}}$ & Number of Obs. $=212 \mathrm{HHs}$
\end{tabular}

Comparison 1: nonmigrant sending against temporary migrant sending households

\begin{tabular}{|c|c|c|c|c|c|c|c|c|c|}
\hline \multirow{2}{*}{$\begin{array}{l}\text { Adj. } \\
R^{2}\end{array}$} & \multirow{2}{*}{ F-stat. } & \multicolumn{2}{|c|}{$Y_{R}$} & \multicolumn{2}{|c|}{$Y_{F}$} & \multicolumn{2}{|c|}{$\mathrm{MC}$} & \multicolumn{2}{|c|}{ Const. } \\
\hline & & Coeff. & $t$-stat. & Coeff. & $t$-stat. & Coeff. & $t$-stat. & Coeff. & $t$-stat. \\
\hline 0.342 & $F(3,208)=34.48^{* * *}$ & $\begin{array}{c}0.23^{* * *} \\
(0.06)\end{array}$ & 3.86 & $\begin{array}{c}0.09^{* * *} \\
(0.011)\end{array}$ & 8.39 & $\begin{array}{l}-0.21 \\
(0.58) \\
\end{array}$ & -0.36 & $\begin{array}{l}432.4^{* *} \\
(173.53)\end{array}$ & 2.49 \\
\hline
\end{tabular}

$K_{(P)}=\delta_{0}+\delta_{1} Y_{R}+\delta_{2} Y_{F}+\delta_{3} \mathrm{MC}+\varepsilon_{K_{P}}$

Number of Obs. $=177 \mathrm{HHs}$

Comparison 2: nonmigrant sending against permanent migrant sending households

\begin{tabular}{|c|c|c|c|c|c|c|c|c|c|}
\hline \multirow{2}{*}{$\begin{array}{l}\text { Adj. } \\
R^{2}\end{array}$} & \multirow{2}{*}{$F$-stat } & \multicolumn{2}{|c|}{$Y_{R}$} & \multicolumn{2}{|c|}{$Y_{F}$} & \multicolumn{2}{|c|}{$\mathrm{MC}$} & \multicolumn{2}{|c|}{ Const. } \\
\hline & & Coeff. & $t$-stat & Coeff. & $t$-stat & Coeff. & $t$-stat & Coeff. & $t$-stat \\
\hline 0.274 & $F(3,173)=21.77^{* * *}$ & $\begin{array}{c}0.08 \\
(0.057)\end{array}$ & 1.40 & $\begin{array}{c}0.09^{* * *} \\
(0.011)\end{array}$ & 7.82 & $\begin{array}{c}-0.20 \\
(0.616)\end{array}$ & -0.33 & $\begin{array}{c}621.6^{* * *} \\
(177.11)\end{array}$ & 3.51 \\
\hline
\end{tabular}

${ }^{*}$ refers to significant at $10 \%(P<0.1) ;{ }^{* *}$ refers to significant at $5 \%(P<0.05)$ and ${ }^{* * *}$ refers to significance at $1 \%(P<0.01)$.

Robust standard errors are found in parenthesis, source: author's estimation.

In general, the estimation results and test statistics confirm the hypothesis that remittances and farm income positively affect the capital stock whereas the effect of cost of migration on capital stock of migrant sending households is negligible.

\subsection{Impact of Rural-Urban Migration on Farm Income.} Table 3 presents the second stage of estimation results where the predicted values of the first stage estimation are regressed on farm income. The variable land is also included as an exogenous variable in the second stage model as one of the determinant factors affecting farm income of rural households.

The effects of outmigration and remittances have been embedded on labor and capital variables in the first stage of analysis and then the predicted values are in turn used to estimate the effect on farm income in the second stage. The results for both types of comparisons in Table 3 indicate that about $84.2 \%$ and $91.1 \%$ of the variations in farm income are explained by the changes in labor, capital stock, and farm land holding in temporary and permanent migrant sending households, respectively. The estimation in comparison 1 shows that one percent increase in the labor hours leads to a $0.26 \%$ increase in farm income of temporary migrant sending households. Comparison 1 shows that the marginal product of labor is still positive and outmigration has made labor productive in temporary migrant sending households compared to the case of nonmigrant sending households. On the other hand, a 1.13\% increase in farm income has been estimated for a one percent increase in the capital stock, which is invested as a result of savings from remittances and farm income. The estimation results in both comparisons 1 and 2 show the role of capital stock in determining farm income is larger than the rest of production factors and taking the largest share in determining production. In this regard, remittances play an important role for investment in capital stock creating a gap in terms of capital stock holdings between migrant sending and nonmigrant sending households (as both types of comparisons are made against nonmigrant sending households). In addition, a one percent increase in size of farm land increases the farm income of temporary migrant sending households by $0.23 \%$.

In the second type of comparison (the comparison made between nonmigrant sending and permanent migrant sending households), the effect of labor on farm income has produced insignificant results in both cropping seasons. Labor has been found to be surplus among permanent migrant sending households where the marginal product of labor is insignificant for each additional unit of labor used in the production process. In this regard, outmigration of labor has produced negligible effect on farm income, keeping the other variables constant. Moreover, the estimation shows that a one percent increase in capital stock leads to a $1.68 \%$ increase in farm income of permanent migrant sending households, where remittances and farm income are the determinant factors for investment in capital stock. In this regard, cost of migration has been found to have insignificant effect on capital stock and thus having negligible effect on farm income. In addition, the estimation result shows that farm income of permanent migrant sending households has increased by $0.11 \%$ for a $1 \%$ increase in the size of land.

The sum of the coefficients of the production factors exceeds one, which is not in line with the assumption of the Cobb-Douglass production function. The production function assumes that the sum of the coefficients of the production factors is summed up to one and applied for macrolevel analysis. The analysis has been done at micro- (household) level and could not hold the homogenous assumption of the production function. As it is already discussed in the previous chapters, migrant sending households decide to send migrants either temporarily or permanently based on the resources they have and expected benefits from migration and possible effects on farm production.

\section{Concluding Remarks}

The determinants of labor and capital inputs and then the effects on total farm income have been discussed by comparing temporary and permanent patterns of migration. Twostep estimation models have been used where the first stage 
TABLE 3: Second stage estimation results.

$\ln Y_{F(T)}=\eta_{1}+\alpha_{1} \ln \widehat{L}_{(T)}+\beta_{1} \ln \widehat{K}_{(T)}+\gamma_{1} \ln \operatorname{Ld}_{(T)}+\varepsilon_{Y_{F(T)}}$

Comparison 1: nonmigrant sending against temporary migrant sending households

Number of Obs. $=212 \mathrm{HHs}$

\begin{tabular}{llccccccc}
\hline $\begin{array}{l}\text { Adj. } \\
R^{2}\end{array}$ & \multicolumn{2}{c}{$\ln \widehat{L}_{(T)}$} & \multicolumn{2}{c}{$\ln \widehat{K}_{(T)}$} & \multicolumn{2}{c}{$\ln \operatorname{Ld}_{(T)}$} & \multicolumn{2}{c}{ Const. } \\
& Coeff. & $Z$ & Coeff. & $Z$ & Coeff. & $Z$ & Coeff. & $Z$ \\
\hline 0.842 & $F(3,208)=275.7^{* * *}$ & $\begin{array}{c}0.26^{* * *} \\
(0.09)\end{array}$ & 2.97 & $\begin{array}{c}1.13^{* * *} \\
(0.072)\end{array}$ & 15.77 & $\begin{array}{c}0.23^{* * *} \\
(0.058)\end{array}$ & 4.08 & -1.32 \\
\hline
\end{tabular}

$\ln Y_{F(P)}=\eta_{2}+\alpha_{2} \ln \widehat{L}_{(P)}+\beta_{2} \ln \widehat{K}_{(P)}+\gamma_{2} \ln \operatorname{Ld}_{(P)}+\varepsilon_{Y_{F(P)}}$

Comparison 2: nonmigrant sending against permanent migrant sending households

No. Obs. $=177 \mathrm{HHs}$

\begin{tabular}{|c|c|c|c|c|c|c|c|c|c|}
\hline \multirow{2}{*}{$\begin{array}{l}\text { Adj. } \\
R^{2}\end{array}$} & \multirow{2}{*}{$F$-stat. } & \multicolumn{2}{|c|}{$\ln \widehat{L}_{(P)}$} & \multicolumn{2}{|c|}{$\ln \widehat{K}_{(P)}$} & \multicolumn{2}{|c|}{$\ln \operatorname{Ld}_{(P)}$} & \multicolumn{2}{|c|}{ Const. } \\
\hline & & Coeff. & $Z$ & Coeff. & $Z$ & Coeff. & $Z$ & Coeff. & $Z$ \\
\hline 0.911 & $F(3,173)=279.4^{* * *}$ & $\begin{array}{l}0.14^{*} \\
(0.080)\end{array}$ & 1.72 & $\begin{array}{l}1.68^{* * *} \\
(0.075)\end{array}$ & 22.39 & $\begin{array}{l}0.11^{* * *} \\
(0.039)\end{array}$ & 2.79 & $\begin{array}{c}-4.35^{* * *} \\
(0.666)\end{array}$ & -6.53 \\
\hline
\end{tabular}

${ }^{*}$ refers to significant at $10 \%(P<0.1) ;{ }^{* *}$ refers to significant at $5 \%(P<0.05)$ and ${ }^{* * *}$ refers to significance at $1 \%(P<0.01)$.

Bootstrap standard errors (as noted by Petrin and Train [17] and Karaca-Mandic and Train [18] bootstrapping methods applied for the entire two-step estimators provide a valid estimator of the covariance matrix which is similar to the estimation done to correct the asymptotic standard errors by programming the asymptotic formula of covariance estimates. Bootstrapping is a convenient way of obtaining the covariance matrix estimators with two-step estimators and it also provides better parameter estimates particularly for conditions when asymptotic sampling distribution is too difficult to drive in multistage estimations $[19,20]$. In this research, bootstrapping method is applied for the entire procedure of the two-step estimators with 1000 replications using STATA software package) are in parenthesis, source: author's estimation

estimates the determinants that affect the allocation of labor and capital inputs and in the second stage the effects on farm income have been analyzed based on the estimation results in the first stage. On one hand, outmigration has been found to reduce the available labor of migrant sending households and on the other hand remittance income has played an important role in boosting the capital stock of migrant sending households. The effect on farm income based on the results of the first stage estimations has shown that migrant sending households have obtained higher income from farm than nonmigrant sending households despite the fact that outmigration reduces the available labor in migrant sending households. The marginal product labor among temporary migrant sending households has remained positive whereas the labor input has been found to be insignificant in determining the farm income in the case of permanent migrant sending households. The independent comparisons made between temporary and permanent migrant sending households in relation to nonmigrant sending households show that temporary migrant sending households have gained higher income from farm compared to nonmigrant sending households due to higher productivity of labor and higher amount of remittances received from migrants. From the results, it is possible to deduce that rural-urban migration has positive effect on farm income as well as it is an important livelihood strategy and in this regard, migrant sending households made a rational decision in sending out migrants in the study area.

\section{Conflict of Interests}

The author declares that there is no conflict of interests regarding the publication of this paper.

\section{References}

[1] P. C. Bhattacharya, "Rural-urban migration in economic development," Journal of Economic Surveys, vol. 7, no. 3, pp. 243-281, 1993.

[2] H. Waddington and R. Sabates-Wheeler, How Does Poverty Affect Migration Choice? A Review of Literature, Development Research Centre on Migration, Globalisation and Poverty, 2003.

[3] M. J. Greenwood and G. L. Hunt, "The early history of migration research," International Regional Science Review, vol. 26, no. 1, pp. 3-37, 2003.

[4] W. Naude, "The determinants of migration from sub-saharan African countries," Journal of African Economies, vol. 19, no. 3, pp. 330-356, 2010

[5] M. J. Greenwood, "Human migration: theory, models, and empirical studies," Journal of Regional Science, vol. 25, no. 4, pp. 521-544, 1985.

[6] E. Ivan, "Internal migration: a review of the literature," MPRA Paper No. 8783, University of Cagliari, 2008.

[7] L. Marchiori, J. F. Maystadt, and I. Scumacher, "Another inconvenient truth: climate change and migration in Sub-Saharan Africa," in Proceedings of the Conference on the Transnationality of Migrants (TOM) Marie Curie Research Training Network 'International Migration: Transnational Links, Effects and Policies', Venice International University, September 2010.

[8] M. Lipton, "Migration from rural areas of poor countries: the impact on rural productivity and income distribution," World Development, vol. 8, no. 1, pp. 1-24, 1980.

[9] J. E. Taylor, "The new economics of labour migration and the role of remittances in the migration process," International Migration, vol. 37, no. 1, pp. 63-88, 1999.

[10] A. de Brauw, J. E. Taylor, and S. Rozelle, Migration and Incomes in Source Communities: A New Economics of Migration Perspective from China, 2001. 
[11] M. R. Rosenzweig, "Risk, implicit contracts and the family in rural areas of low-income countries," The Economic Journal, vol. 98, no. 393, pp. 1148-1170, 1988.

[12] J. E. Taylor, J. Arango, G. Hugo, A. Kouaouci, D. S. Massey, and A. Pellegrino, "International migration and community development," Population index, vol. 62, no. 3, pp. 397-418, 1996.

[13] F. Gubert, "Migration, remittances and moral hazard. Evidence from the Kayes Area (Western Mali)," CERDI-CNRS, Etudes et Documents E 2000.17, 2000.

[14] SESRTCIC (Statistical, Economic and Social Research and Training Center for Islamic countries), Poverty in Sub-SaharaPn Africa, The situation in the OIC member countries, no. 4, G.O.P. 06700, Ankara, Turkey, 2007.

[15] M. Demeke, F. Guta, and T. Ferede, "Growth, employment, poverty \& policies in Ethiopia: an empirical investigation," Issues in Employment and Poverty Discussion Paper 12, Recovery and Reconstruction Department, International Labor Office, Geneva, Switzerland, 2003.

[16] J. R. Harris and M. P. Todaro, "Migration, unemployment and development: a two-sector analysis," The American Economic Association, vol. 60, no. 1, pp. 126-142, 1970.

[17] A. Petrin and K. Train, Omitted Product Attributes in Discrete Choice Models, University of Chicago and University of California, Berkeley, Calif, USA, 2002.

[18] P. Karaca-Mandic and K. Train, "Standard error correction in two-stage estimation with nested samples," The Econometrics Journal, vol. 6, no. 2, pp. 401-407, 2003.

[19] K. Schmidheiny, Short Guides to Micro-Econometrics: The Bootstrap, Universität Basel, 2012.

[20] D. Freedman, "On bootstrapping two-stage least-squares estimates in stationary linear models," The Annals of Statistics, vol. 12, no. 3, pp. 827-842, 1984. 


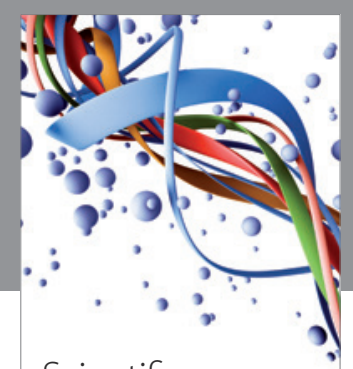

Scientifica
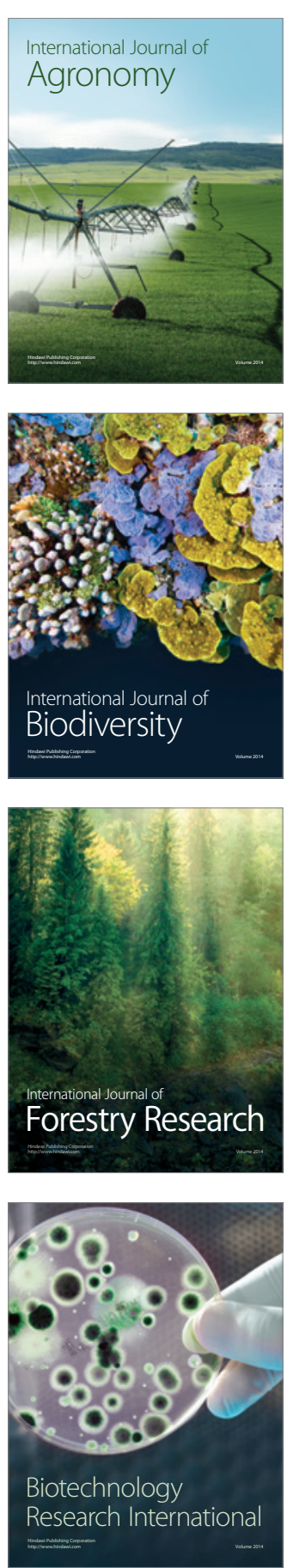
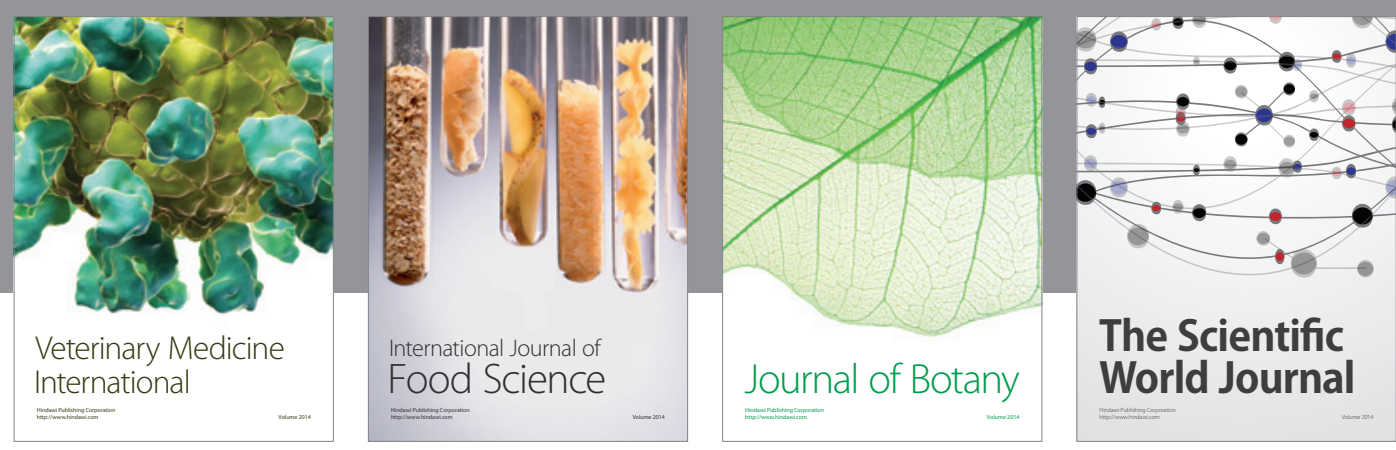

The Scientific World Journal
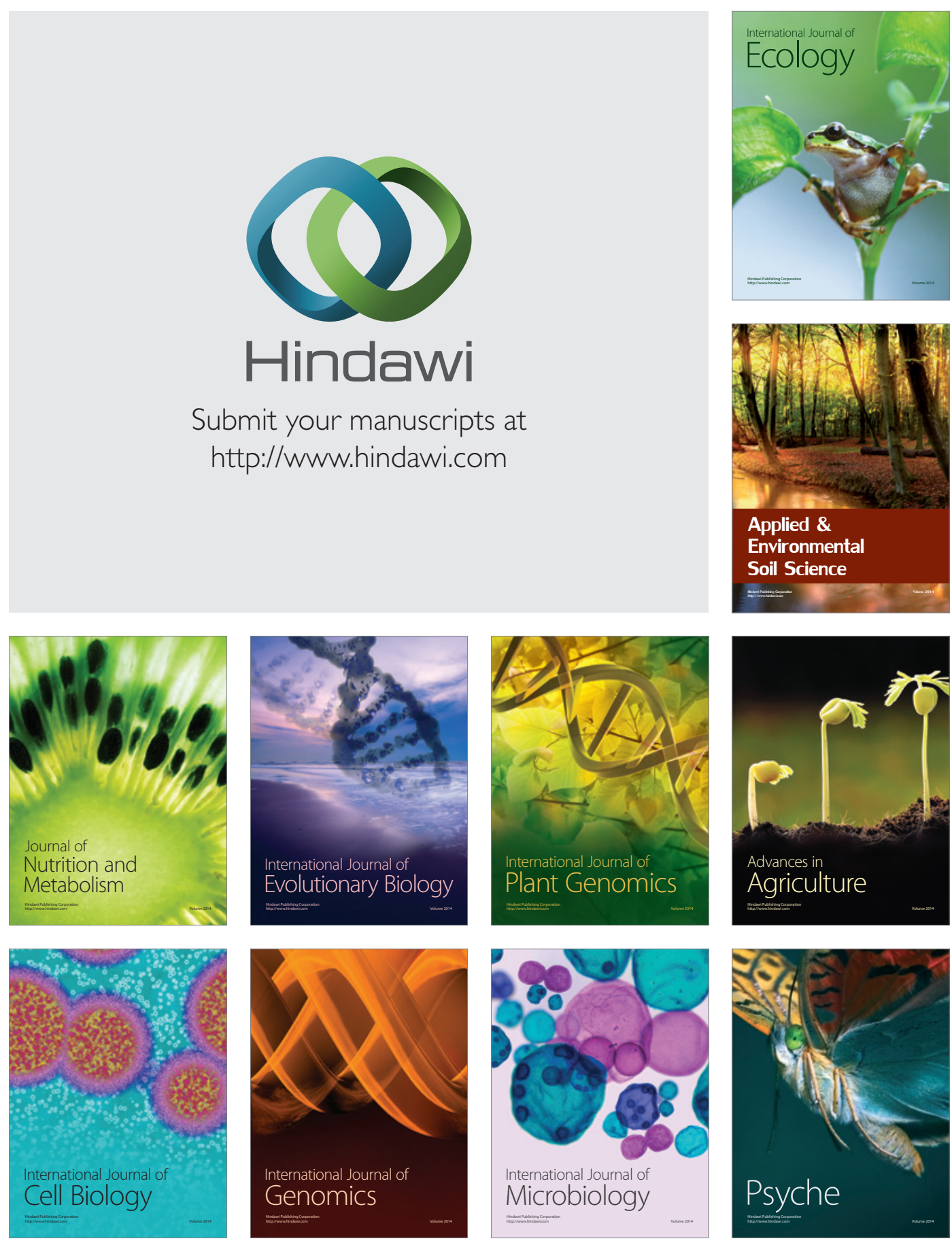